\title{
Doratoxylon apetalum, an Indigenous Medicinal Plant from Mascarene Islands, Is a Potent Inhibitor of Zika and Dengue Virus Infection in Human Cells
}

\author{
Juliano G. Haddad ${ }^{1}$, Andrea Cristine Koishi ${ }^{2}{ }^{-}$, Arnaud Gaudry ${ }^{3}$, \\ Claudia Nunes Duarte dos Santos ${ }^{2}$, Wildriss Viranaicken ${ }^{1} \mathbb{D}$, Philippe Desprès ${ }^{1} \mathbb{D}$ and \\ Chaker El Kalamouni 1,*(D) \\ 1 Université de la Réunion, INSERM U1187, CNRS UMR 9192, IRD UMR 249, Unité Mixte Processus \\ Infectieux en Milieu Insulaire Tropical, Plateforme Technologique CYROI, 94791 Sainte Clotilde, La Réunion, \\ France; juliano.haddad@univ-reunion.fr (J.G.H.); wildriss.viranaicken@univ-reunion.fr (W.V.); \\ philippe.despres@univ-reunion.fr (P.D.) \\ 2 Laboratorio de Virologia Molecular, Instituto Carlos Chagas, ICC/FIOCRUZ/PR, Curitiba, Parana 81350-010, \\ Brazil; ackoishi@gmail.com (A.C.K.); clsantos@fiocruz.br (C.N.D.d.S.) \\ 3 Bioactive natural products unit, School of Pharmaceutical Sciences, EPGL, University of Geneva, \\ Rue Michel-Servet 1, CH-1211 Geneva, Switzerland; Arnaud.gaudry@unige.ch \\ * Correspondence: chaker.el-kalamouni@univ-reunion.fr; Tel.: +262-262-938822
}

Received: 10 April 2019; Accepted: 12 May 2019; Published: 14 May 2019

\begin{abstract}
Zika virus (ZIKV) and Dengue virus (DENV) are mosquito-borne viruses of the Flavivirus genus that could cause congenital microcephaly and hemorrhage, respectively, in humans, and thus present a risk to global public health. A preventive vaccine against ZIKV remains unavailable, and no specific antiviral drugs against ZIKV and DENV are licensed. Medicinal plants may be a source of natural antiviral drugs which mostly target viral entry. In this study, we evaluate the antiviral activity of Doratoxylum apetalum, an indigenous medicinal plant from the Mascarene Islands, against ZIKV and DENV infection. Our data indicated that D. apetalum exhibited potent antiviral activity against a contemporary epidemic strain of ZIKV and clinical isolates of four DENV serotypes at non-cytotoxic concentrations in human cells. Time-of-drug-addition assays revealed that D. apetalum extract acts on ZIKV entry by preventing the internalisation of virus particles into the host cells. Our data suggest that $D$. apetalum-mediated ZIKV inhibition relates to virus particle inactivation. We suggest that $D$. apetalum could be a promising natural source for the development of potential antivirals against medically important flaviviruses.
\end{abstract}

Keywords: Zika virus; dengue virus; antiviral activity; medicinal plant; nutraceuticals; polyphenol; Doratoxylon apetalum.

\section{Introduction}

Zika virus (ZIKV) and the closely related dengue virus (DENV) are mosquito-borne RNA viruses of the genus Flavivirus in the Flaviviridae family [1]. ZIKV has recently emerged as a public health threat because of its rapid spread in the world, sexual transmission and vertical human-to-human transmission, and its association with congenital malformations and neurological disorders [2-4]. The disease burden due to four dengue serotypes (DENV 1-4) has recently been revised, and accordingly, about 390 million infections occur annually in over 100 countries in tropical and sub-tropical regions of the world [5].

Flavivirus genomic RNA consists of a single ORF, translated into a polyprotein, and processed to yield 3 structural (capsid [C], premembrane [prM] and envelope [E]) and 7 nonstructural (NS1 to NS5) 
proteins which play an important role in the replication of the virus [6]. After the binding of virus particles to the cell surface receptors, their internalisation can occur through a clathrin-dependent pathway. The structural rearrangement of the E protein mediates virus-to-cell membrane fusion, releasing viral nucleocapsid into the cytosol. The fusion of the viral envelope with the endosomal membrane requires a low-pH environment $[7,8]$.

At present, there are no therapeutics licensed against ZIKV and DENV infections. Given that many countries worldwide remain at risk of ZIKV and DENV outbreaks due to the prevalence of Aedes spp. vectors $[5,9,10]$, it is of utmost urgency to develop safe and effective antivirals by exploring the potential of medicinal plants as natural sources of nutraceuticals that could be used to prevent virus infection [11-17]. The use of polyphenol-rich medicinal plants and their purified compounds as potential antiviral therapies has been recently explored [11,12,15,18-24]. Several phytochemical families including polyphenols, flavonoids, alkaloids and curcuminoids have been reported to inhibit flavivirus infection $[18,21,22,24-27]$. It has been demonstrated that epigallocatechin gallate (EGCG) from green tea, isoquercitrin (Q3G) and curcumin impair ZIKV and DENV infection [17,18,21,28-30]. We described that EGCG acts on the early stage of ZIKV and DENV infection by inhibiting the binding of the virus to the cell surface [12,24,29], whereas Q3G inhibits the internalisation process of ZIKV infection in human cells [22]. Recent studies have demonstrated that a polyphenol-rich extract from Doratoxylon apetalum, an indigenous medicinal plant from the Mascarene Islands, was able to protect cells from oxidative stress due to its high polyphenolic content [31,32]. In the present study, we showed that $D$. apetalum extract exerts an antiviral effect against ZIKV and DENV in human cells.

\section{Results and Discussion}

\subsection{D. apetalum is an Effective Suppresor of ZIKV Infection at Non-Cytotoxic Concentration}

Doratoxylon apetalum extract was first tested on Vero, A549, and Huh7.5 cells for cytoxicity using a 3-[4,5-dimethylthiazol-2-yl]-2,5- diphenyltetrazolium bromide (MTT) assay. D. apetlum extract showed little or no cytotoxicity at concentrations $<200 \mu \mathrm{g} \cdot \mathrm{mL}^{-1}$ regardless of the cell lines tested (Figure 1). Huh7.5 cells were the most sensitive for $D$. apetalum extract. The $50 \%$ cytotoxic concentration $\left(C_{50}\right)$ were 1250, 560 and $350 \mu \mathrm{g} \cdot \mathrm{mL}^{-1}$ for Vero, A549 and Huh7.5 cell lines, respectively (Figure 1). Therefore, various concentrations of plant extract up to $200 \mu \mathrm{g} \cdot \mathrm{mL}^{-1}$ were used in the futher experiments.

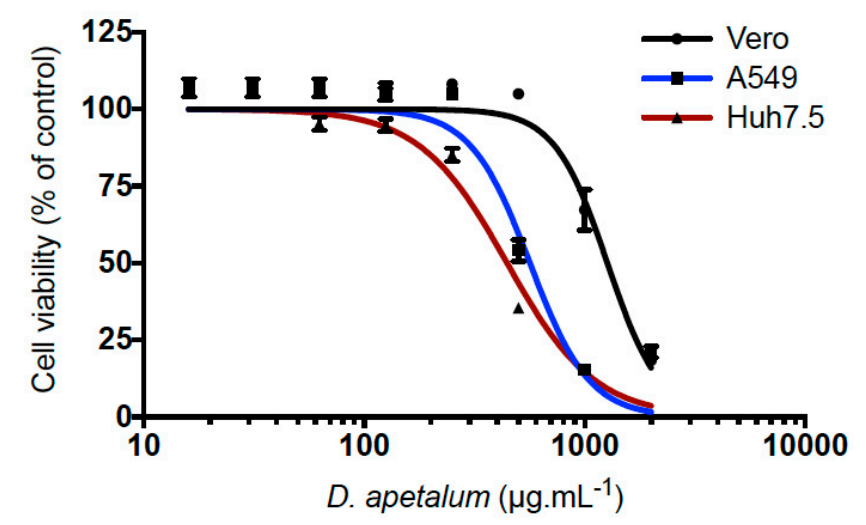

Figure 1. The cytotoxicity of D. apetalum extract on different cell lines. Vero, A549 and Huh7.5 cell lines were incubated with different concentrations of D. apetalum extract for $72 \mathrm{~h}$. A 3-[4,5-dimethylthiazol2-yl]-2,5- diphenyltetrazolium bromide (MTT) assay was performed to evaluate cell viability. Results are means $\pm \mathrm{SD}$ of four independent experiments and are expressed as relative values compared to untreated cells.

Given that human lung epithelial A549 cells support infection by the epidemic strain PF-25013-18 (PF13) of ZIKV, PF13-infected A549 cells were used to evaluate the anti-ZIKV activity of D. apetalum extract. By immunofluorescence analysis using anti-flavivirus $\mathrm{E}$ mAb 4G2, we showed that $D$. 
apetalum extract severely restricted ZIKV infection in A549 cells yielding a 75\% inhibition of ZIKV infection at $50 \mu \mathrm{g} \cdot \mathrm{mL}^{-1}$ (Figure $2 \mathrm{~A}$ ). Likewise, viral protein production was severely inhibited in a concentration-dependent manner (Figure 2B). At the higher non-cytotoxic concentration of $100 \mu \mathrm{g} \cdot \mathrm{mL}^{-1}$, D. apetalum extract reduced the viral progeny production by at least $5 \log _{10}$ (Figure $2 C$ ). No viral growth was detected at $200 \mu \mathrm{g} \cdot \mathrm{mL}^{-1}$ of $D$. apetalum extract, indicating that such a concentration provided near complete protection against PF13 infection. Altogether, these data demonstrate that $D$. apetalum extract can efficiently inhibit ZIKV infection in A549 cells in a dose-dependent manner and reflect its potential as a source of natural antiviral phytochemicals.

A.

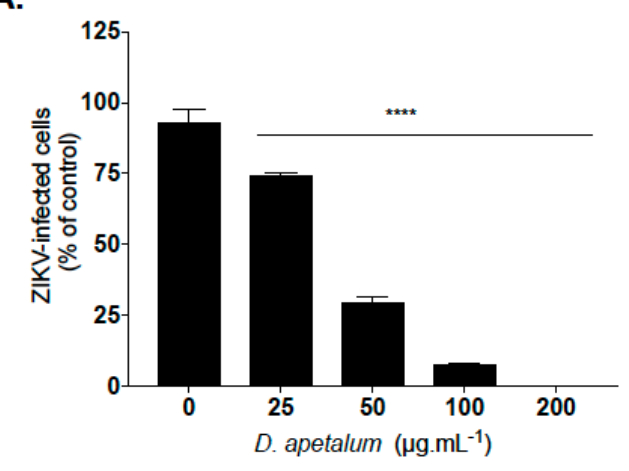

B.

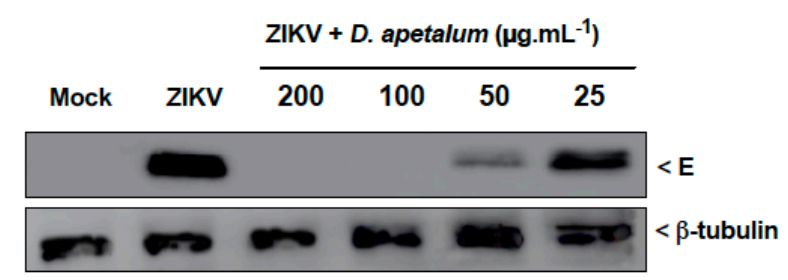

C.

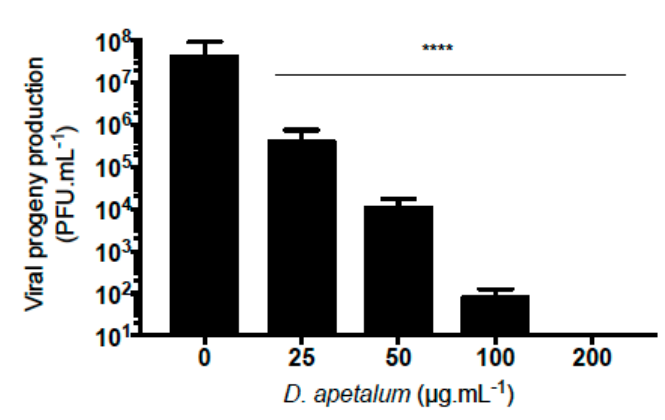

Figure 2. D. apetalum extract prevents infection of A549 cells by epidemic strain of Zika virus (ZIKV). A549 cells wer e infected with PF-25013-18 at a multiplicity of infection (MOI) of 2 and continuously incubated with different non-cytotoxic concentrations of D. apetalum extract. (A) Immunofluorescence analysis of viral protein expression in ZIKV-infected A549 cells. (B) Detection of intracellular E protein in ZIKV-infected A549 cells by immunoblot assay using anti-E mAb. $\beta$-tubulin served as loading control. (C) ZIKV progeny production was quantified by plaque-forming assay. Data represent the means \pm SD from four independent experiments. One-way ANOVA and Dunnett's test were used for statistical analysis $(* * * * p<0.0001)$.

\subsection{D. apetalum Extract Inhibits Infection by Four DENV Serotypes}

We next wondered if $D$. apetalum extract has a potential antiviral activity against DENV, another medically interesting flavivirus. Thus, the antiviral activity of $D$. apetalum extract was evaluated using four different clinical isolates representing four DENV serotypes. IFN- $\alpha 2 \mathrm{~A}$, which is known to block 
DENV replication [12], was used as positive control. Huh7.5 cells were inoculated with four DENV serotypes in the presence or absence of different non-cytotoxic concentrations of $D$. apetalum extract. The number of infected cells were quantified at $48 \mathrm{~h}$ post-infection (h.pi) by immunofluorescence assay using the Operetta high-content imaging system [12]. Our data demonstrate that D. apetalum extract exerts an antiviral effect against the four DENV serotypes and epidemic Brazilian strain ZIKV-BR of ZIKV in a dose-dependent manner (Figure 3 ). The $50 \%$ inhibitory concentration ( $\mathrm{IC}_{50}$ ) values were 96.35, 16.75, 25.90, 23.30, and $17.50 \mu \mathrm{g} \cdot \mathrm{mL}^{-1}$ for DENV1-4 and ZIKV-BR, respectively. DENV-2 appears to be the most sensitive virus. The selectivity index (SI), which measures the preferential antiviral activity of a drug in a relation to its cytotoxicity [22], was calculated according to their $\mathrm{CC}_{50}$ and $\mathrm{IC}_{50}$ established using non-linear regression curve (Figure S1). The SIs were 2.7, 17.8, 11.3, 13.0 and 16.8 for DENV1-4 and ZIKV-BR, respectively (Table 1). DENV-1 was the least sensitive virus against D. apetalum extract.

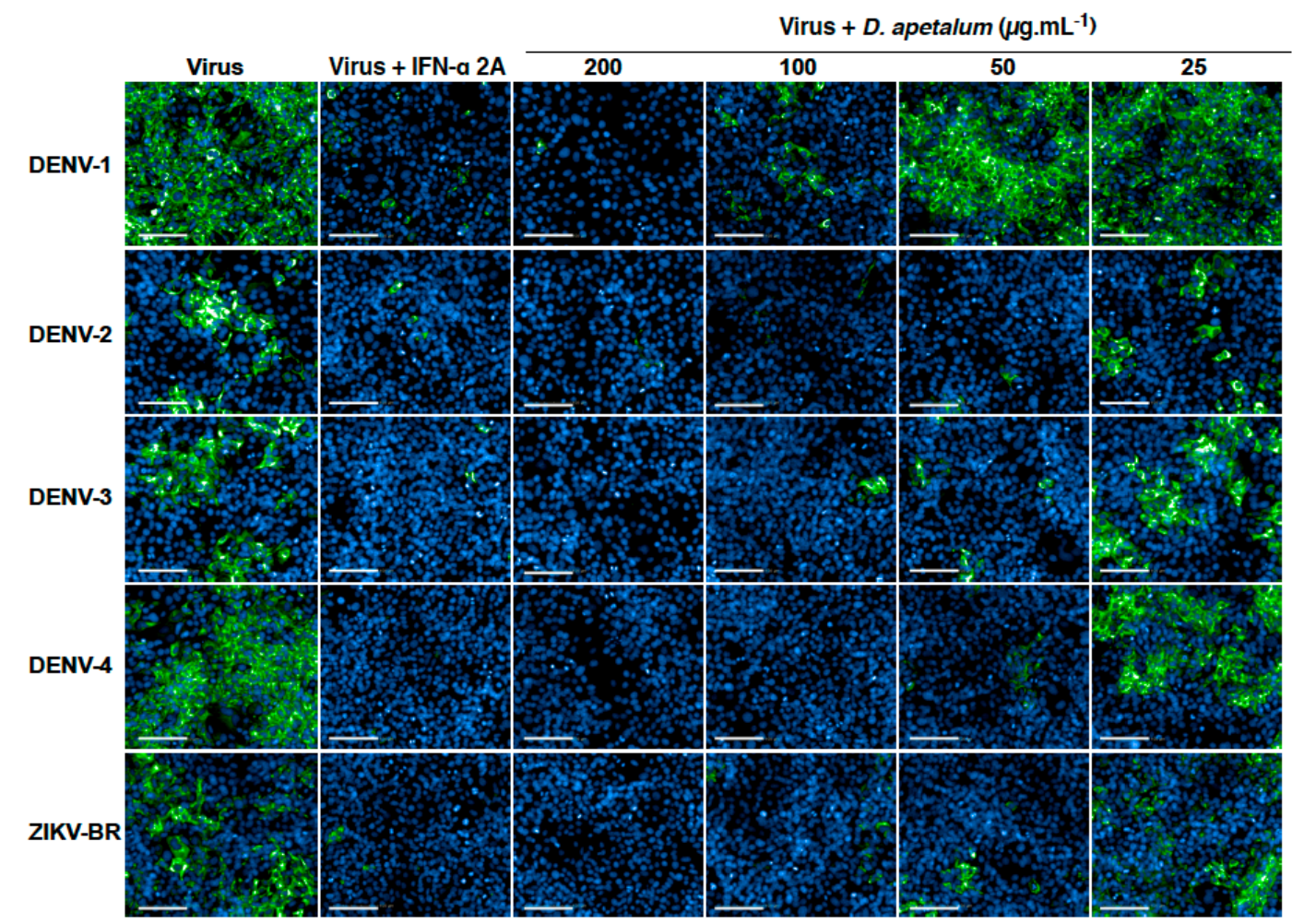

Figure 3. D. apetalum extract exhibits antiviral effect against the four Dengue virus (DENV) serotypes and an epidemic Brazilian strain of ZIKV. Huh7.5 cells were infected during $48 \mathrm{~h}$ with DENV-1 (MOI 2), DENV-2 (MOI 2), DENV-3 (MOI 0.5) or DENV-4 (MOI 2). Cells were infected for $48 \mathrm{~h}$ with the epidemic Brazilian strain (ZIKV-BR) of ZIKV at MOI 2. Infected Huh7.5 cells were continuously incubated with different non-cytotoxic concentrations of D. apetalum extract for $48 \mathrm{~h}$. Recombinant IFN- $\alpha 2 \mathrm{~A}$ (200 IU.mL ${ }^{-1}$ ) was added $2 \mathrm{~h}$ post infection and used as a positive control. Immunofluorescence assay was performed using anti-flavivirus $\mathrm{E}$ mAb $4 \mathrm{G} 2$. The percentage of immunostained cells was determined using the Operetta High-Content Imaging System. Scale bars are $100 \mu \mathrm{m}$. 
Table 1. Cytotoxicity and antiviral activity of D. apetalum extract.

\begin{tabular}{|c|c|c|c|}
\hline Virus & $\mathrm{CC}_{50}\left(\mu \mathrm{g} \cdot \mathrm{mL}^{-1}\right)^{\mathrm{a}}$ & $\mathrm{IC}_{50}\left(\mu \mathrm{g} \cdot \mathrm{mL}^{-1}\right)^{\mathrm{b}}$ & $S I^{d}$ \\
\hline DENV-1 & 263.5 & 96.35 & 2.7 \\
\hline DENV-2 & 299.0 & 16.75 & 17.8 \\
\hline DENV-3 & 293.0 & 25.90 & 11.3 \\
\hline DENV-4 & 303.0 & 23.30 & 13.0 \\
\hline ZIKV & 295.5 & 17.50 & 16.8 \\
\hline
\end{tabular}

Cytotoxic concentrations $\left(\mathrm{CC}_{50}\right)$ and inhibitory concentrations $\left(\mathrm{IC}_{50}\right)$ were obtained by performing nonlinear regression followed by the construction of sigmoidal concentration-response curves from Figure S1. ${ }^{\text {a }}$ Concentration that inhibited cell viability by $50 \%{ }^{\text {b }}$ concentration that inhibited infection by $50 \%$; ${ }^{\mathrm{d}}$ selectivity index $\left(\mathrm{CC}_{50} / \mathrm{IC}_{50}\right)$.

\subsection{D. apetalum Extract-Mediated Inhibition of ZIKV Occurs at the Early Stage of the Viral Infetious Cycle}

To further characterize the antiviral mechanism and the stage of ZIKV infection affected by $D$. apetalum extract, we examined the impact of the plant extract on various stages of the dissected virus replication cycle (pre-entry, entry and post-entry). In addition, wash steps were included to ensure the specificity of the treatment on the distinct stage examined [22,33]. In order to study pre-entry-more specifically, the ability of D. apetalum to induce host cell innate immunity prior virus addition [34] —A549 cells were pretreated with D. apetalum $\left(200 \mu \mathrm{g} \cdot \mathrm{mL}^{-1}\right)$ for $6 \mathrm{~h}$ (Figure $4 \mathrm{~A}$ : pre-treatment). For effects on the viral entry stage, ZIKV and D. apetalum extract were simultaneously co-added to the cells during $2 \mathrm{~h}$ (Figure 4A: coaddition). To investigate events after virus entry, A549 cells were first infected with ZIKV for $2 \mathrm{~h}$ and then treated with D. apetalum (Figure 4A: post-infection). For comparison, $D$. apetalum extract was also maintained throughout the experimental period. Pretreating A549 cells with $D$. apetalum extract slightly protects against ZIKV infection $(p<0.05)$. Compared to the pretreatment of the cells with $D$. apetalum extract or to adding it in the entry stage or post-infection phase, the anti-ZIKV effect was most evident during the coaddition treatment, yielding a significant reduction in GFP-positive cells (90\% of inhibition, $p<0.001$ ) (Figure 4B). These results therefore suggest that the antiviral activity of $D$. apetalum extract are unlikely to be mediated by effects through triggering antiviral innate immunity or viral replication. All together, these data suggest that $D$. apetalum targets the initial stages of ZIKV infection, whereby both virus and plant extract are present on the cell surface.

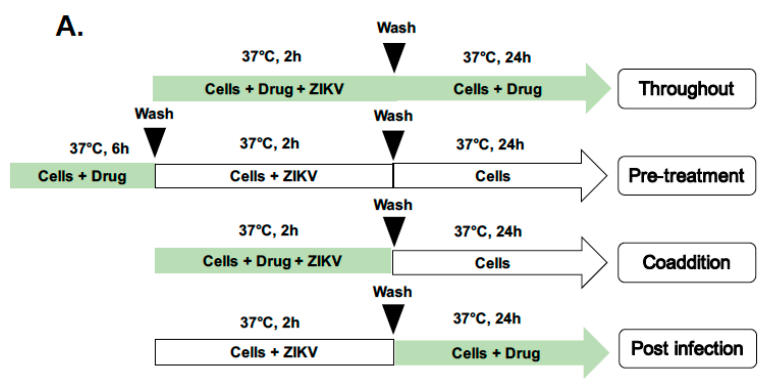

B.

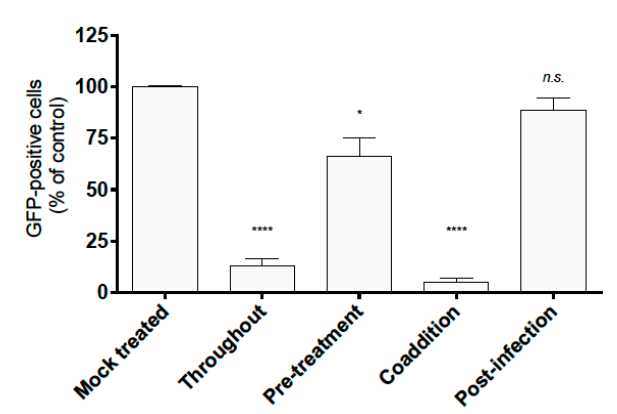

Figure 4. D. apetalum extract targets early stages of the ZIKV replication cycle. (A) Schematic representation of the time-of-drug-addition assay used to characterize antiviral activity of $D$. apetalum extract $\left(200 \mu \mathrm{g} \cdot \mathrm{mL}^{-1}\right)$ on ZIKV GFP infection of A549 cells. Green arrows indicate the presence of plant extract. (B) Results of GFP-expression in ZIKV ${ }^{\mathrm{GFP}}$-infected A549 cells under different experimental conditions, shown in A, are analysed by flow cytometry assay. The data represent the means \pm SD of four independent experiments and are expressed as relative values compared to the mock-treated control. One-way ANOVA and Dunnett's test were used for statistical analysis $\left({ }^{*} p<0.05 ;{ }^{* * * *} p<0.0001\right.$; $n . s=$ not significant). 


\subsection{D. apetalum Extract Prevents ZIKV Entry by Inactivating Virus Particles}

To further elucidate the underlying mechanism, we subsequently tested the influence of D. apetlaum on specific ZIKV entry steps. We first investigated whether D. apetalum directly affects the cell-free virions to abolish subsequent infection (Figure 5A) [12,34]. For this, ZIKV particles were pre-incubated with $D$. apetalum extract for $2 \mathrm{~h}$ and then diluted 50 -fold prior to infection. This dilution titrates the plant extract below its therapeutic concentration and prevents potential interactions with the host cell surface (Figure 5A). Flow cytometry and viral titration assays showed that ZIKV infectivity was severely affected by D. apetalum extract yielding a $90 \%$ inhibition of infection as well as $3 \log _{10}$ of viral progeny reduction (Figure 5A). Thus, $D$. apetalum extract could irreversibly interact with virus particules to prevent infection. Altogether, these results suggest that phytochemicals present in $D$. apetalum extract could bind to virus particles and neutralize virus infectivity.

A.

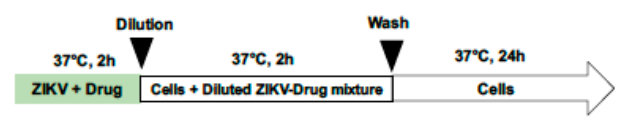

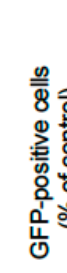

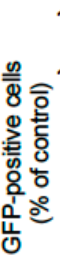

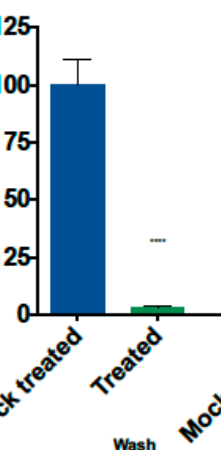

c.
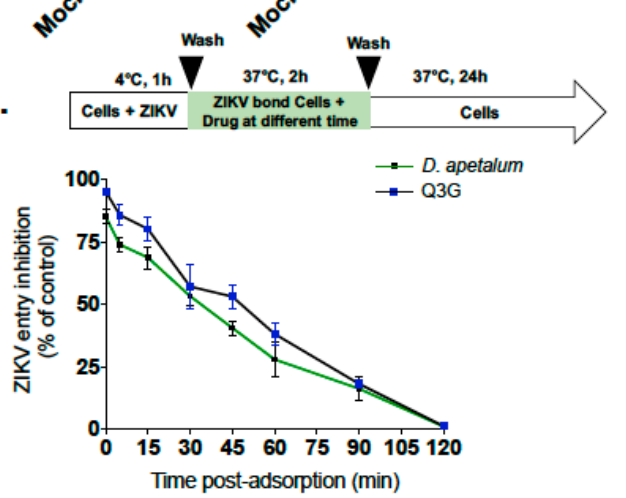

B.
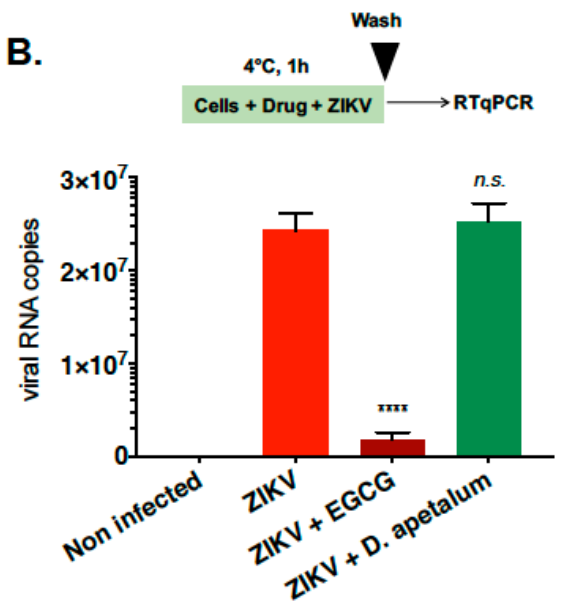

Figure 5. D. apetalum extract prevents ZIKV entry in A549 cells by inactivating virus particles. (A) Viral inactivation assay. ZIKVGFP $\left(2.10^{5}\right.$ plaque forming unit (PFU)) was mixed with D. apetalum extract (200 $\mu \mathrm{g} \cdot \mathrm{mL}^{-1}$ ) for $2 \mathrm{~h}$ at $37^{\circ} \mathrm{C}$ and then diluted 50-fold (final concentration, $1 \mathrm{PFU} / \mathrm{cell}$ ) before infecting A549 cells. As a control, the same amount of virus was also mixed with $D$. apetalum extract but diluted immediately and applied to the A549 cells. Flow cytometric analysis of GFP fluorescence or viral titration using plaque forming assay were performed 24 h.pi. (B) A549 cells were infected with ZIKV at MOI of 1 for $1 \mathrm{~h}$ at $4{ }^{\circ} \mathrm{C}$ with or without $200 \mu \mathrm{g} \cdot \mathrm{mL}^{-1}$ of D. apetalum extract. EGCG $(100 \mu \mathrm{M})$ was used as positive control. The number of virus particles bound to the cell surface was measured by RT-qPCR. (C) A549 cells were incubated for $1 \mathrm{~h}$ with ZIKV ${ }^{\mathrm{GFP}}$ at $4{ }^{\circ} \mathrm{C}$. D. apetalum extract was added at different time points post temperature shift during $2 \mathrm{~h}$. Q3G $(200 \mu \mathrm{M})$ was used as a positive control. Data represent the means $\pm \mathrm{SD}$ of three independent experiments performed in triplicate. One-way ANOVA and Dunnett's test were used for statistical analysis $\left({ }^{* * * *} p<0.0001 ; n . s=\right.$ not significant).

We next assessed the ability of $D$. apetalum extract to affect viral attachment. The attachment assays were performed at $4{ }^{\circ} \mathrm{C}$, which allows for virus binding but prevents viral entry (Figure 5B) [35]. The polyphenol EGCG, which is known to inhibit ZIKV attachment $[12,19,24]$, was used as a positive 
control. After $1 \mathrm{~h}$ of ZIKV attachment with or without D. apetalum, the number of attached ZIKV particles was evaluated using RT-qPCR (Figure 5B). Our data show that the number of viral particles attached to the cell surface membrane was similar to untreated cells. As expected, EGCG significantly inhibits ZIKV attachment to the cell membrane (Figure 5B). The absence of difference in the amount of viral particles attached to the cell membrane compared to untreated cells suggests that the incapacity of ZIKV to initiate productive infection in the presence of $D$. apetalum extract was not related to a defect in cell-attachment (Figure 5B). Altogether, the results showed that D. apetalum extract prevents ZIKV entry in the host cell without affecting the attachment step.

Our previous antiviral assays showed that the D. apetalum extract-mediated inhibition of ZIKV is related to a virus inactivation affecting post-attachment step(s) in the infectious virus cycle. To further assess the effect of $D$. apetalum extract on the virus internalisation step, ZIKV particles were allowed to bind to $\mathrm{A} 549$ cells at $4{ }^{\circ} \mathrm{C}$, without $D$. apetalum treatment, and were subsequently internalized into the host cell by shifting the temperature to $37^{\circ} \mathrm{C}$ in the presence of D. apetalum extract (Figure 5C). Isoquercitrin (Q3G), which is known to inhibit the ZIKV internalisation process in A549 cells, was used as a positive control [22]. Both D. apetalum and Q3G showed a similar time-course of ZIKV entry inhibition with a maximum of effect during the first 30 min post-binding (Figure 5C). This result suggests that $D$. apetalum has the ability to inhibit the early steps of virus internalisation into the host cell.

Altogether, these data provide evidence that D. apetalum extract-mediated inhibition of ZIKV infection occurs early after virus binding to the plasma membrane and could be explained by the inability of the plasma membrane-associated virus to be internalized into the host cell in presence of plant extract.

\subsection{Concluding Remarks}

Currently, there is no specific treatment available against ZIKV and DENV infections [5,9]. Therefore, the development of natural substances as nutraceuticals able to inhibit virus infection represents an attractive preventive strategy [11,36]. In this field, medicinal plants may be a source of promising natural antiviral compounds against emerging arboviruses $[11,12,17,18,21,22,27,29,30,37]$. In this study, we report that an extract from Dorotoxylon apetalum, an indigenous medicinal plant from the Mascarene Islands, inhibits infection of A549 and Huh7.5 cells by epidemic ZIKV and DENV strains without reducing cell viability. In addition, our results suggest that $D$. apetalum extract could bind to ZIKV particles, rendering the virus incapable of initiating an infectious viral cycle. Pretreatment of host cells with $D$. apetalum, followed by washes to remove unadsorbed phytochemicals, had a slight effect upon ZIKV infection. That indicated that masking cell surface receptors or entry factors for ZIKV is likely [34]. Viral binding assays using RT-qPCR reveals that $D$. apetalum extract does not interfere with viral attachment to the host cell membrane. While D. apetalum extract could inactivate the ZIKV particles, we do not believe that a direct lysis effect of the viral membrane is responsible for their effects, since ZIKV attachment to the cell membrane can occur with $D$. apetalum. Future experiments using confocal microscopy will be undertaken to validate our assumption that D. apetalum-mediated ZIKV inhibition essentially relates to a lack of virus internalisation into the host cell [38].

Our data demonstrate that $D$. apetalum-mediated flavivirus inhibition is linked to a severe loss of viral infectivity and a lack of virus internalisation into the host cells. Whether a single or several phytochemical(s) can contribute to the antiviral action of D. apetalum is a critical issue that remains to be investigated. It is also a high priority to determine which viral factors are targeted by the phytochemical(s) present in D. apetalum. The flavivirus E protein plays a key role in the recognition of the flavivirus receptors at the cell surface and the subsequent internalisation of virus particles into the endosomal compartment where viral membrane-cell membrane fusion can take place, releasing the viral genome into the cytosol $[1,6-8,39,40]$. It would be of interest to evaluate whether $\mathrm{E}$ protein is the main target of D. apetalum's active molecules, thus explaining the inability of DENV and ZIKV to initiate a productive infectious cycle in the host cells. 
The results presented in this study underscore the entry antagonist as a promising class of antivirals and add D. apetalum to the group of medicinal plant extracts or phytochemicals that interfere with the early stage of the ZIKV replication cycle [11,12,20,41-43]. We recently reported that both extracts from Aphloia theiformis and Psiloxylon mauritianum, indigenous medicinal plants from Reunion Island, inactivate cell-free virions, as well as EGCG, impeding virus binding to the host cell surface by deforming ZIKV particles [12,20]. In addition, we recently described the mechanism of action of isoquercitrin (Q3G) that targets the internalisation process of ZIKV in different human cell lines [22]. In conclusion, we demonstrated that $D$. apetalum belongs to the growing list of Mascarene Islands plants which enable ZIKV and DENV inhibition at the virus entry level.

\section{Materials and Methods}

\subsection{Cells, Viruses and Reagents}

Human lung epithelial A549 cells (ATCC, CCL-185, Manassas, VA, USA), Vero cells (ATCC, CCL-81) and human-derived Huh-7 hepatoma cells (ATCC, PTA-8561) were grown in minimum essential medium (MEM: Gibco/Invitrogen, Carlsbad, CA, USA) supplemented with 10\% heat-inactivated fetal bovine serum (FBS Good: Invitrogen), $2 \mathrm{mmol} \cdot \mathrm{L}^{-1} \mathrm{~L}$-Glutamine, $1 \mathrm{mmol} \cdot \mathrm{L}^{-1}$ sodium pyruvate, $100 \mathrm{U} \cdot \mathrm{mL}^{-1}$ of penicillin, $0.1 \mathrm{mg} \cdot \mathrm{mL}^{-1}$ of streptomycin and $0.5 \mu \mathrm{g} \cdot \mathrm{mL}^{-1}$ of fungizone (PAN Biotech) under a $5 \% \mathrm{CO}_{2}$ atmosphere at $37^{\circ} \mathrm{C}$. The clinical isolate PF-25013-18 of ZIKV (ZIKV- PF13) and the recombinant Zika virus expressing the GFP reporter gene (ZIKV ${ }^{\mathrm{GFP}}$ ) have been previously described [44,45]. Virus stocks were cultured and titrated on Vero cells using plaque-forming assay. DENV-1/FGA/89 was isolated in 1989 from a South American patient suffering from DF (GenBank: AF226687). DENV-2/ICC-265 was isolated from a DF patient in Brazil in 2009. DENV3/97 was isolated from a Dengue patient from north of Brazil in 2004 [46]. DENV-4/422 was isolated isolated in 2013 from a Brazilian Dengue patient with hemorrhagic manifestation [47]. The brazilian clinical isolate of Zika virus (ZK BR 2015/15261) was isolated from a patient with Zika fever from Northeast of Brazil in 2015. DENV stocks were grown in C6/36 cells and titrated by foci-forming immunodetection assay. Anti-pan flavivirus E monoclonal antibody 4G2-Alexa Fluor 594 was purchased from RD Biotech.

\subsection{Extraction of Plant Material}

Fresh aerial parts of Doratoxylon apetalum were collected in 2014, 2015 and 2017 in various locations of Reunion Island. Voucher specimens (T-1097) were deposited in the herbarium of the University of Reunion Island. Dried leaves $(12.5 \mathrm{~g}$ ) were reduced to powder and extracted by soaking in $50 \mathrm{~mL}$ ethanol:water (70:30) at room temperature for $24 \mathrm{~h}$. Ethanol was then evaporated using a Rotavapor and aqueous phase was lyophilized using cryotec 20K (Cryotec, Saint-Gély-du-Fesc, France) to produce a brown powder. The crude extracts were solubilized in sterile phosphate buffer saline (PBS) and stored at $-80^{\circ} \mathrm{C}$ until used for the antiviral assays.

\subsection{MTT Assay}

Cells were cultured in a 96-well culture plate at a density of $1.5 \times 10^{4}$ cells per well and treated with two-fold dilutions of plant extract ranging from $200 \mu \mathrm{g} \cdot \mathrm{mL}^{-1}$ to $25 \mu \mathrm{g} \cdot \mathrm{mL}^{-1}$. After a treatment period of $72 \mathrm{~h}$ at $37^{\circ} \mathrm{C}$, cells were rinsed with PBS $1 \times$ and $120 \mu \mathrm{L}$ of culture medium mixed with $5 \mathrm{mg} \cdot \mathrm{mL}^{-1}$ MTT (3-[4,5-dimethylthiazol-2-yl]-2,5- diphenyltetrahzolium bromide) solution was added to the cell monolayer. Incubation was extended for $2 \mathrm{~h}$, then MTT medium was removed and the formazan crystals were solubilized with $50 \mu \mathrm{L}$ of dimethyl sulfoxide (DMSO) [12]. Absorbance was measured at $570 \mathrm{~nm}$ with a background subtraction at $690 \mathrm{~nm}$. The $\mathrm{CC}_{50}$ was determined using a nonlinear regression on Graphpad prism software. 


\subsection{Immunofluorescence and Flow Cytometry Assays}

For cytometry assay, cells were harvested, fixed with 3.7\% PFA in PBS for 20 min and subjected to a flow cytometric analysis using Cytoflex (Beckman Coulter, Brea, California, USA). Results were analyzed using cytexpert software. For immunofluorescence assay, cells grown on glass coverslips were fixed (PFA 3.7\%) for $10 \mathrm{~min}$, permeabilized for $4 \mathrm{~min}$ (PBS $1 \times 0.15 \%$ Triton X-100). Cells were stained for $1 \mathrm{~h}$ at room temperature in the dark for ZIKV using 4G2-Alexa 594 (1:1000 in PBS-BSA $2 \%$ ). DAPI staining was used to delineate cell nuclei. Coverslips were mounted in Vectashield and the fluorescence was observed using Nikon Eclipse E2000-U microscope. Hamamatsu ORCA-ER camera and NIS-Element AR (Nikon, Melville, NY, USA) imaging software were used to capture images.

\subsection{Virus Inactivation Assay}

To assess the direct effect of the extract on viral infectivity, ZIKV GFP $\left(2 \times 10^{5}\right.$ plaque forming unit (PFU)) were mixed with extract at $200 \mu \mathrm{g} \cdot \mathrm{mL}^{-1}$ and then incubated at $37^{\circ} \mathrm{C}$ for $2 \mathrm{~h}$. The mixture was diluted 50-fold (final virus concentration, 1 PFU/cell) in MEM containing 10\% FBS to yield a subtherapeutic concentration of extract, and this mixture was subsequently added to A549 cells monolayer seeded in a 6-well plates. As a comparison, ZIKVGFP was mixed with extract, diluted immediately to 50-fold (no incubation period) and added to cells for infection [12]. After $2 \mathrm{~h}$ of adsorption at $37^{\circ} \mathrm{C}$, the diluted inocula were discarded, and cells were washed with PBS twice. Medium overlay was applied and the plates were further incubated at $37^{\circ} \mathrm{C}$ for $24 \mathrm{~h}$. Cells and supernatants were collected and subjected to a flow cytometric analysis.

\subsection{Western Blot}

Cell lysates were performed in RIPA lysis buffer. All subsequent steps of immunoblotting were performed as previously described [22]. Primary antibodies were used at 1:1000 dilutions. Anti-mouse immunoglobulin-horseradish peroxidase conjugates was used as secondary antibody (dilution 1:500). Blots were revealed with ECL detection reagents.

\subsection{Plaque Forming Assay}

Viral progeny production was determined by plaque-forming assay as previously described with minor modifications [22]. Briefly, Vero cells grown in 48-well culture plate were infected by 0.1 $\mathrm{mL}$ of ten-fold dilutions of supernatants. Following an incubation of $2 \mathrm{~h}$ at $37^{\circ} \mathrm{C}, 0.2 \mathrm{~mL}$ of culture medium supplemented with $5 \%$ fetal bovine serum (FBS) and $0.8 \%$ carboxymethylcellulose sodium salt (Sigma-Aldrich, Saint-Quentin-Fallavier, France) were added, and the incubation was extended for 4 days at $37^{\circ} \mathrm{C}$. The cells were fixed (PFA 3.7\%) and stained with $0.5 \%$ crystal violet (Sigma-Aldrich) diluted in $20 \%$ ethanol, after the media had been removed. Plaques were counted and expressed as plaque-forming unit per $\mathrm{mL}\left(\mathrm{PFU} \cdot \mathrm{mL}^{-1}\right)$.

\section{8. $R T-q P C R$}

Total RNA including genomic viral RNA was extracted from cells with RNeasy kit (Qiagen) and reverse transcribed using E reverse primer (5'-TTCACCTTGTGTTGGGC-3') and M-MLV reverse transcriptase (Life Technologies, Villebon-sur-Yvette, France) at $42{ }^{\circ} \mathrm{C}$ for $50 \mathrm{~min}$. Quantitative PCR was performed on a CFX96 Real-Time PCR Detection System (Bio-Rad). Briefly, cDNA were amplified using $0.2 \mu \mathrm{M}$ of each primer and GoTaq Master Mix (Promega, Charbonnières-les-bains, France). For each single-well amplification reaction, a threshold cycle (Ct) was calculated using the CFX96 program (Bio-Rad, Life Science, Marnes-la-Coquette, France) in the exponential phase of amplification. A synthetic gene coding for nucleotides 954 to 1306 of the MR766 strain (GenBank: LC002520) cloned in the pUC57 plasmid was used as template to generate a standard curve, which then served to make absolute quantitation of bound viruses. 


\subsection{Data analysis}

Comparison between different concentrations was done by a one-way ANOVA test. All values were expressed as mean $\pm \mathrm{SD}$ of at least three independent experiments. All statistical tests were done using the software Graph-Pad Prism (version 7.0; GraphPad software, La Jola, CA, USA). Degrees of significance are indicated on the figure as follows: ${ }^{*} p<0.05 ;{ }^{* *} p<0.01 ;{ }^{* * *} p<0.001,{ }^{* * * *} p<0.0001$, n.s. $=$ not significant.

Supplementary Materials: Supplementary Materials can be found at http://www.mdpi.com/1422-0067/20/10/ 2382/s1.

Author Contributions: Conceptualization, C.E.K.; methodology, J.G.H., A.C.K., A.G., C.E.K.; validation, C.E.K.; formal analysis, J.G.H., A.C.K., A.G., W.V., C.N.D.d.S., P.D., C.E.K.; investigation, J.G.H., A.C.K., A.G., W.V., C.N.D.d.S., P.D., C.E.K.; writing-original draft preparation, J.G.H., C.E.K.; writing-review and editing, J.G.H., P.D., C.E.K.; supervision, C.E.K.; funding acquisition, P.D., C.E.K.

Funding: Research was funded by POE FEDER 2014-20 of the Conseil Régional de La Réunion (ZIKAlert program, No. SYNERGIE: RE00001902), CAPES-COFECUB Me889/17 ZIKANET project and Research Federation BioST, Université de La Réunion. J.G.H. received funding from the ZIKAlert program. A.G. has a Master degree scholarship from Swiss-European Mobility program from University of Geneva (Switzerland).

Conflicts of Interest: The authors declare no conflict of interest. The funders had no role in the design of the study; in the collection, analyses, or interpretation of data; in the writing of the manuscript, or in the decision to publish the results.

$\begin{array}{ll}\text { Abbreviations } \\ \text { A549 } & \text { Human lung epithelial cell line } \\ \text { DENV } & \text { Dengue virus } \\ \text { EGCG } & \text { Epigallocatechin gallate } \\ \text { h.pi } & \text { Hours post infection } \\ \text { Huh-7.5 } & \text { Human hepatoma cell line } \\ \text { MOI } & \text { Multiplicity of infection } \\ \text { MTT } & \text { 3-[4,5-dimethylthiazol-2-yl]-2,5- diphenyltetrazolium } \\ \text { PFU } & \text { bromide } \\ \text { Q3G } & \text { Plaque forming unit }\end{array}$

\section{References}

1. Huber, R.G.; Lim, X.N.; Ng, W.C.; Sim, A.Y.L.; Poh, H.X.; Shen, Y.; Lim, S.Y.; Sundstrom, K.B.; Sun, X.; Aw, J.G.; et al. Structure mapping of dengue and Zika viruses reveals functional long-range interactions. Nat. Commun. 2019, 10, 1408. [CrossRef]

2. Cao-Lormeau, V.-M.; Blake, A.; Mons, S.; Lastère, S.; Roche, C.; Vanhomwegen, J.; Dub, T.; Baudouin, L.; Teissier, A.; Larre, P.; et al. Guillain-Barré Syndrome outbreak associated with Zika virus infection in French Polynesia: A case-control study. Lancet 2016, 387, 1531-1539. [CrossRef]

3. Chen, J.; Liang, Y.; Yi, P.; Xu, L.; Hawkins, H.K.; Rossi, S.L.; Soong, L.; Cai, J.; Menon, R.; Sun, J. Outcomes of Congenital Zika Disease Depend on Timing of Infection and Maternal-Fetal Interferon Action. Cell Rep. 2017, 21, 1588-1599. [CrossRef] [PubMed]

4. Ma, W.; Li, S.; Ma, S.; Jia, L.; Zhang, F.; Zhang, Y.; Zhang, J.; Wong, G.; Zhang, S.; Lu, X.; et al. Zika Virus Causes Testis Damage and Leads to Male Infertility in Mice. Cell 2017, 168, 542. [CrossRef] [PubMed]

5. Bos, S.; Gadea, G.; Despres, P. Dengue: A growing threat requiring vaccine development for disease prevention. Pathog. Glob. Health 2018, 112, 294-305. [CrossRef] [PubMed]

6. Perera-Lecoin, M.; Meertens, L.; Carnec, X.; Amara, A. Flavivirus Entry Receptors: An Update. Viruses 2013, 6, 69-88. [CrossRef]

7. Meertens, L.; Labeau, A.; Dejarnac, O.; Cipriani, S.; Sinigaglia, L.; Bonnet-Madin, L.; Le Charpentier, T.; Hafirassou, M.L.; Zamborlini, A.; Cao-Lormeau, V.-M.; et al. Axl Mediates ZIKA Virus Entry in Human Glial Cells and Modulates Innate Immune Responses. Cell Rep. 2017, 18, 324-333. [CrossRef] 
8. Laureti, M.; Narayanan, D.; Rodriguez-Andres, J.; Fazakerley, J.K.; Kedzierski, L. Flavivirus Receptors: Diversity, Identity, and Cell Entry. Front. Immunol. 2018, 9, 2180. [CrossRef]

9. Mittal, R.; Nguyen, D.; Debs, L.H.; Patel, A.P.; Liu, G.; Jhaveri, V.M.; S Kay, S.-I.; Mittal, J.; Bandstra, E.S.; Younis, R.T.; et al. Zika Virus: An Emerging Global Health Threat. Front. Cell Infect. Microbiol. 2017, 7, 486. [CrossRef]

10. Pascalis, H.; Turpin, J.; Roche, M.; Krejbich, P.; Gadea, G.; Nten, C.A.; Desprès, P.; Mavingui, P. The epidemic of Dengue virus type-2 Cosmopolitan genotype on Reunion Island relates to its active circulation in the Southwestern Indian Ocean neighboring islands. Heliyon 2019, 5, e01455. [CrossRef]

11. Byler, K.G.; Ogungbe, I.V.; Setzer, W.N. In-silico screening for anti-Zika virus phytochemicals. J. Mol. Graph. Model 2016, 69, 78-91. [CrossRef] [PubMed]

12. Clain, E.; Sinigaglia, L.; Koishi, A.C.; Gorgette, O.; Gadea, G.; Viranaicken, W.; Krejbich-Trotot, P.; Mavingui, P.; Desprès, P.; Nunes Duarte Dos Santos, C.; et al. Extract from Aphloia theiformis, an edible indigenous plant from Reunion Island, impairs Zika virus attachment to the host cell surface. Sci. Rep. 2018, 8, 10856. [CrossRef] [PubMed]

13. Norahmad, N.A.; Mohd Abd Razak, M.R.; Mohmad Misnan, N.; Md Jelas, N.H.; Sastu, U.R.; Muhammad, A.; Ho, T.C.D.; Jusoh, B.; Zolkifli, N.A.; Thayan, R.; et al. Effect of freeze-dried Carica papaya leaf juice on inflammatory cytokines production during dengue virus infection in AG129 mice. BMC Complement. Altern. Med. 2019, 19, 44. [CrossRef] [PubMed]

14. Perera, S.D.; Jayawardena, U.A.; Jayasinghe, C.D. Potential Use of Euphorbia hirta for Dengue: A Systematic Review of Scientific Evidence. J. Trop. Med. 2018, 2018, 2048530. [CrossRef]

15. Sharma, N.; Mishra, K.P.; Chanda, S.; Bhardwaj, V.; Tanwar, H.; Ganju, L.; Kumar, B.; Singh, S.B. Evaluation of anti-dengue activity of Carica papaya aqueous leaf extract and its role in platelet augmentation. Arch. Virol. 2019, 164, 1095-1110. [CrossRef]

16. Tahir Ul Qamar, M.; Maryam, A.; Muneer, I.; Xing, F.; Ashfaq, U.A.; Khan, F.A.; Anwar, F.; Geesi, M.H.; Khalid, R.R.; Rauf, S.A.; et al. Computational screening of medicinal plant phytochemicals to discover potent pan-serotype inhibitors against dengue virus. Sci. Rep. 2019, 9, 1433. [CrossRef] [PubMed]

17. Zandi, K.; Lim, T.-H.; Rahim, N.-A.; Shu, M.-H.; Teoh, B.-T.; Sam, S.-S.; Danlami, M.-B.; Tan, K.-K.; Abubakar, S. Extract of Scutellaria baicalensis inhibits dengue virus replication. BMC Complement. Altern. Med. 2013, 13, 91. [CrossRef]

18. Balasubramanian, A.; Pilankatta, R.; Teramoto, T.; Sajith, A.M.; Nwulia, E.; Kulkarni, A.; Padmanabhan, R. Inhibition of dengue virus by curcuminoids. Antivir. Res. 2019, 162, 71-78. [CrossRef] [PubMed]

19. Carneiro, B.M.; Batista, M.N.; Braga, A.C.S.; Nogueira, M.L.; Rahal, P. The green tea molecule EGCG inhibits Zika virus entry. Virology 2016, 496, 215-218. [CrossRef]

20. Clain, E.; Haddad, J.G.; Koishi, A.C.; Sinigaglia, L.; Rachidi, W.; Despres, P.; Duarte Dos Santos, C.N.; Guiraud, P.; Jouvenet, N.; El Kalamouni, C. The Polyphenol-Rich Extract from Psiloxylon mauritianum, an Endemic Medicinal Plant from Reunion Island, Inhibits the Early Stages of Dengue and Zika Virus Infection. Int. J. Mol. Sci. 2019, 20, 1860. [CrossRef] [PubMed]

21. Frabasile, S.; Koishi, A.C.; Kuczera, D.; Silveira, G.F.; Verri, W.A.; Duarte Dos Santos, C.N.; Bordignon, J. The citrus flavanone naringenin impairs dengue virus replication in human cells. Sci. Rep. 2017, 7, 41864. [CrossRef]

22. Gaudry, A.; Bos, S.; Viranaicken, W.; Roche, M.; Krejbich-Trotot, P.; Gadea, G.; Despres, P.; El-Kalamouni, C. The Flavonoid Isoquercitrin Precludes Initiation of Zika Virus Infection in Human Cells. Int. J. Mol. Sci. 2018, 19, 1093. [CrossRef]

23. Ledoux, A.; Cao, M.; Jansen, O.; Mamede, L.; Campos, P.-E.; Payet, B.; Clerc, P.; Grondin, I.; Girard-Valenciennes, E.; Hermann, T.; et al. Antiplasmodial, anti-chikungunya virus and antioxidant activities of 64 endemic plants from the Mascarene Islands. Int. J. Antimicrob. Agents 2018, 52, 622-628. [CrossRef] [PubMed]

24. Sharma, N.; Murali, A.; Singh, S.K.; Giri, R. Epigallocatechin gallate, an active green tea compound inhibits the Zika virus entry into host cells via binding the envelope protein. Int. J. Biol. Macromol. 2017, 104, 1046-1054. [CrossRef]

25. Calland, N.; Sahuc, M.-E.; Belouzard, S.; Pène, V.; Bonnafous, P.; Mesalam, A.A.; Deloison, G.; Descamps, V.; Sahpaz, S.; Wychowski, C.; et al. Polyphenols Inhibit Hepatitis C Virus Entry by a New Mechanism of Action. J. Virol. 2015, 89, 10053-10063. [CrossRef] 
26. Lani, R.; Hassandarvish, P.; Shu, M.-H.; Phoon, W.H.; Chu, J.J.H.; Higgs, S.; Vanlandingham, D.; Abu Bakar, S.; Zandi, K. Antiviral activity of selected flavonoids against Chikungunya virus. Antivir. Res. 2016, 133, 50-61. [CrossRef] [PubMed]

27. Weber, C.; Sliva, K.; Von Rhein, C.; Kümmerer, B.M.; Schnierle, B.S. The green tea catechin, epigallocatechin gallate inhibits chikungunya virus infection. Antivir. Res. 2015, 113, 1-3. [CrossRef] [PubMed]

28. Paemanee, A.; Hitakarun, A.; Roytrakul, S.; Smith, D.R. Screening of melatonin, alpha-tocopherol, folic acid, acetyl-L-carnitine and resveratrol for anti-dengue 2 virus activity. BMC Res. Notes 2018, 11, 307. [CrossRef] [PubMed]

29. Vázquez-Calvo, Á.; Jiménez De Oya, N.; Martín-Acebes, M.A.; Garcia-Moruno, E.; Saiz, J.-C. Antiviral Properties of the Natural Polyphenols Delphinidin and Epigallocatechin Gallate against the Flaviviruses West Nile Virus, Zika Virus, and Dengue Virus. Front. Microbiol. 2017, 8, 1314. [CrossRef] [PubMed]

30. Zainal, N.; Chang, C.P.; Cheng, Y.L.; Wu, Y.W.; Anderson, R.; Wan, S.W.; Chen, C.L.; Ho, T.S.; AbuBakar, S.; Lin, Y.S. Resveratrol treatment reveals a novel role for HMGB1 in regulation of the type 1 interferon response in dengue virus infection. Sci. Rep. 2017, 7, 42998. [CrossRef]

31. Dobi, A.; Bravo, S.B.; Veeren, B.; Paradela-Dobarro, B.; Alvarez, E.; Meilhac, O.; Viranaicken, W.; Baret, P.; Devin, A.; Rondeau, P. Advanced glycation end-products disrupt human endothelial cells redox homeostasis: New insights into reactive oxygen species production. Free Radic. Res. 2019, 1-20. [CrossRef] [PubMed]

32. Marimoutou, M.; Le Sage, F.; Smadja, J.; Lefebvre D’Hellencourt, C.; Gonthier, M.-P.; Robert-Da Silva, C. Antioxidant polyphenol-rich extracts from the medicinal plants Antirhea borbonica, Doratoxylon apetalum and Gouania mauritiana protect 3T3-L1 preadipocytes against $\mathrm{H}_{2} \mathrm{O}_{2}, \mathrm{TNF} \alpha$ and LPS inflammatory mediators by regulating the expression of superoxide dismut. J. Inflamm. 2015, 12, 10. [CrossRef]

33. Ralambondrainy, M.; Belarbi, E.; Viranaicken, W.; Baranauskiene, R.; Venskutonis, P.R.; Despres, P.; Roques, P.; El Kalamouni, C.; Selambarom, J. In vitro comparison of three common essential oils mosquito repellents as inhibitors of the Ross River virus. PLoS ONE 2018, 13, e0196757. [CrossRef] [PubMed]

34. Lin, L.T.; Chen, T.Y.; Chung, C.Y.; Noyce, R.S.; Grindley, T.B.; McCormick, C.; Lin, T.C.; Wang, G.H.; Lin, C.C.; Richardson, C.D. Hydrolyzable tannins (chebulagic acid and punicalagin) target viral glycoprotein-glycosaminoglycan interactions to inhibit herpes simplex virus 1 entry and cell-to-cell spread. J. Virol. 2011, 85, 4386-4398. [CrossRef] [PubMed]

35. Bos, S.; Viranaicken, W.; Turpin, J.; El-Kalamouni, C.; Roche, M.; Krejbich-Trotot, P.; Desprès, P.; Gadea, G. The structural proteins of epidemic and historical strains of Zika virus differ in their ability to initiate viral infection in human host cells. Virology 2018, 516, 265-273. [CrossRef]

36. Yang, Z.-F.; Bai, L.-P.; Huang, W.-B.; Li, X.-Z.; Zhao, S.-S.; Zhong, N.-S.; Jiang, Z.-H. Comparison of in vitro antiviral activity of tea polyphenols against influenza $A$ and $B$ viruses and structure-activity relationship analysis. Fitoterapia 2014, 93, 47-53. [CrossRef]

37. Johari, J.; Kianmehr, A.; Mustafa, M.; Abubakar, S.; Zandi, K. Antiviral Activity of Baicalein and Quercetin against the Japanese Encephalitis Virus. Int. J. Mol. Sci. 2012, 13, 16785-16795. [CrossRef]

38. Li, F.; Lang, Y.; Ji, Z.; Xia, Z.; Han, Y.; Cheng, Y.; Liu, G.; Sun, F.; Zhao, Y.; Gao, M.; et al. A scorpion venom peptide Ev37 restricts viral late entry by alkalizing acidic organelles. J. Biol. Chem. 2019, 294, 182-194. [CrossRef]

39. Lee, J.K.; Shin, O.S. Advances in Zika Virus-Host Cell Interaction: Current Knowledge and Future Perspectives. Int. J. Mol. Sci. 2019, 20, 1101. [CrossRef]

40. Moller-Tank, S.; Maury, W. Phosphatidylserine receptors: Enhancers of enveloped virus entry and infection. Virology 2014, 468-470, 565-580. [CrossRef]

41. Elgner, F.; Sabino, C.; Basic, M.; Ploen, D.; Grunweller, A.; Hildt, E. Inhibition of Zika Virus Replication by Silvestrol. Viruses 2018, 10, 149. [CrossRef]

42. Lee, J.L.; Loe, M.W.C.; Lee, R.C.H.; Chu, J.J.H. Antiviral activity of pinocembrin against Zika virus replication. Antivir. Res. 2019. [CrossRef] [PubMed]

43. Sze, A.; Olagnier, D.; Hadj, S.B.; Han, X.; Tian, X.H.; Xu, H.T.; Yang, L.; Shi, Q.; Wang, P.; Wainberg, M.A.; et al. Sophoraflavenone G Restricts Dengue and Zika Virus Infection via RNA Polymerase Interference. Viruses 2017, 9, 287. [CrossRef] [PubMed] 
44. Frumence, E.; Roche, M.; Krejbich-Trotot, P.; El-Kalamouni, C.; Nativel, B.; Rondeau, P.; Missé, D.; Gadea, G.; Viranaicken, W.; Desprès, P. The South Pacific epidemic strain of Zika virus replicates efficiently in human epithelial A549 cells leading to IFN- $\beta$ production and apoptosis induction. Virology 2016, 493, 217-226. [CrossRef] [PubMed]

45. Gadea, G.; Bos, S.; Krejbich-Trotot, P.; Clain, E.; Viranaicken, W.; El-Kalamouni, C.; Mavingui, P.; Desprès, P. A robust method for the rapid generation of recombinant Zika virus expressing the GFP reporter gene. Virology 2016, 497, 157-162. [CrossRef] [PubMed]

46. Nogueira, M.B.; Stella, V.; Bordignon, J.; Batista, W.C.; Borba, L.; Silva, L.H.; Hoffmann, F.G.; Probst, C.M.; Santos, C.N. Evidence for the co-circulation of dengue virus type 3 genotypes III and V in the Northern region of Brazil during the 2002-2004 epidemics. Mem. Inst. Oswaldo Cruz. 2008, 103, 483-488. [CrossRef]

47. Kuczera, D.; Bavia, L.; Mosimann, A.L.; Koishi, A.C.; Mazzarotto, G.A.; Aoki, M.N.; Mansano, A.M.; Tomeleri, E.I.; Costa Junior, W.L.; Miranda, M.M.; et al. Isolation of dengue virus serotype 4 genotype II from a patient with high viral load and a mixed Th1/Th17 inflammatory cytokine profile in South Brazil. Virol. J. 2016, 13, 93. [CrossRef]

(C) 2019 by the authors. Licensee MDPI, Basel, Switzerland. This article is an open access article distributed under the terms and conditions of the Creative Commons Attribution (CC BY) license (http://creativecommons.org/licenses/by/4.0/). 